University of Nebraska - Lincoln

DigitalCommons@University of Nebraska - Lincoln

2018

Paleoparasitology and Pathoecology in Russia: Investigations and Perspectives

Sergey Slepchenko

Karl Reinhard

Follow this and additional works at: https://digitalcommons.unl.edu/natresreinhard

Part of the Archaeological Anthropology Commons, Ecology and Evolutionary Biology Commons, Environmental Public Health Commons, Other Public Health Commons, and the Parasitology Commons

This Article is brought to you for free and open access by the Natural Resources, School of at DigitalCommons@University of Nebraska - Lincoln. It has been accepted for inclusion in Karl Reinhard Papers/ Publications by an authorized administrator of DigitalCommons@University of Nebraska - Lincoln. 


\title{
Paleoparasitology and Pathoecology in Russia: Investigations and Perspectives
}

\author{
Sergey Slepchenko ${ }^{1,2}$ and Karl Reinhard ${ }^{3}$
}

1. Institute of the Problems of Northern Development, Tyumen Scientific Centre, Siberian Branch of the Russian Academy of Sciences, Tyumen, Russia

2. Surgut State University, Surgut, Khanty-Mansi, Tyumen, Russia

3. School of Natural Resources, University of Nebraska-Lincoln, Lincoln, Nebraska, USA

Corresponding author - Sergey Slepchenko, email s slepchenko@list.ru

\begin{abstract}
Russia, both as the USSR and the Russian federation, provided a source of parasitological theory for decades. A key figure in Russian parasitology was Yevgeny Pavlovsky. He developed the nidus concept, the conceptual basis for the field of pathoecology. He also coined the term "paleoparasitology." Pathoecology is a foundation concept in archaeological parasitology. Paleoparasitology, as defined by Pavlovsky, is an avenue for understanding of host parasite evolution over very long time periods. These contributions are not fully recognized internationally. Similarly, the long history of Russian paleontological and archaeological investigations are not fully known. Most recently, discoveries from archaeological sites show that a pattern of zoonotic infection prevailed among archaeological populations in central Russia. This included a case of apparent host switching of beef tapeworm infection to reindeer. This latter discovery raises the possibility that archaeological parasitology can contribute to the new Stockholm Paradigm of ecological fitting, host switching, and emergent disease. This review covers all of the parasitological discoveries from ancient Russia and illustrates how Russian models and discoveries defined parasitological theory in the past and present.
\end{abstract}

Keywords: pathoecology, Pavlovsky, nidality, paleoparasitology, archaeoparasitology, Siberia 


\section{Introduction}

In recent years, Russian parasitologists in Russia have increasingly focused on archaeological evidence. The approach in Russia, as in other parts of the world, is based on the nidus model of pathoecology. This approach has special importance in Russia. The pathoecological approach is based on the "natural nidality" concept of Y. Pavlovsky, an extremely important Russian parasitologist and epidemiologist. Notably, Pavlovsky introduced the term "paleoparasitology" in 1948 as applied to paleontological discoveries of the era. However, paleopathologists are, in general, ignorant of Pavlovsky's specific contributions and Russian research in general and specifically the derivation of paleoparasitology from his work. We are taking this opportunity to provide a historical background of Russian research.

Based on Pavlovsky's work, pathoecology is an approach developed by archaeological parasitologists to reconstruct the infection modes and localities within and between sites (Martinson et al., 2003; Reinhard and Araújo, 2014; Reinhard and Araújo, 2016). Specifically, Reinhard and Bryant (2008) established nidality as the underlying conceptual structure of pathoecology. Pathoecology is the interaction between parasitism, nutritional adequacy, and behaviors such as sanitation and medicinal, which define the disease state of a community. Nidality relates to the specific environments in and around the community where infection occurred.

Yevgeny Pavlovsky (1884-1965) was a Russian Soviet parasitologist who introduced the concept of "natural nidality" of parasitic transmission (Pavlovsky, 1966). As a parasitologist and epidemiologist he was recognized in the Soviet Union for his many scientific achievements. Some of his awards were the Stalin State Prize (1941, 1950), the Lenin Prize (1965), the Mechnikov Gold Medal of the Academy of Sciences of the USSR (1949), and gold medal of the Soviet Geographical Society (1954). Outside of the USSR, his seminal work was translated into English by Frederick K. Plous, Jr. and edited by Norman D. Levine. This book was Natural Nidality of Transmissible Diseases, with Special Reference to the Landscape Epidemiology of Zooanthroponoses. In this work, he established the idea that microscale transmission foci are determined by entire ecosystems. In his time, his concept established a foundation for infection preventive measures. After his death, the "natural nidality" concept was used in developing landscape parasitology. It was a major influence in epidemiology and parasitology. Pavlovsky established that most transmissible diseases exist in nature as discrete foci or nidi (sing. nidus, "hearth" or "home"). A nidus is defined as that portion of a natural geographic landscape which contains a community consisting of a pathogen, vectors, reservoir hosts, and recipient hosts and possesses an environment in which the pathogen can circulate. This concept was incorporated by archaeological parasitologists in the concept of pathoecology. Several authors now incorporate Pavlovsky's concept into the reconstruction of archaeological pathoecology (Dittmar et al., 2012; Reinhard, 2008a; Reinhard, 2008b; Reinhard and Araújo, 2012; Reinhard and Araújo, 2014; Bryant and Reinhard 2012; Reinhard and Bryant, 2008). Reinhard and Bryant (2008) developed the nidus concept in the context of archaeological field methods which are designed to uncover microscale features related to specific activities such as food storage, processing, and sanitation. These activities created nidi in the past. These nidi persist as archaeological features to be documented by archaeologists. Using this methodological foundation, 
Reinhard and Araújo (2014) developed a specific research design that archaeologists are implementing in the field to define nidi of Trypanosoma cruzi transmission. It is of significance that the pathoecological approach to ancient parasite transmission had a Russian origin in Y. Pavlovsky. Our review of Russian archaeological parasitology is presented in terms of pathoecology, recognizing the Russian origin of this theoretical approach.

In 2013, the senior author contacted Araújo and Reinhard to begin research collaboration. The resulting partnership resulted in the production of new research. The present article tries to throw light on the main stages of revelation and investigation of parasites in the Russian archaeological context in order to reconstruct aspects of life of the ancient population. We also propose to incorporate Pavlovsky's ideas into future work in Russia.

\subsection{Paleoparasitology as first defined in Russia}

In Russia, the earliest parasitological observations were obtained at the beginning of the 20th century from paleontological contexts. Pavlovsky was aware of past and ongoing research when he composed one of his major works in 1946, Handbook on Parasitology of Man and Theory on Vectors of Transmissive Diseases (Pavlovsky, 1946). In that book (in the Russian version 1946), he introduced "paleoparasitology" as a field that had the potential to contribute to the understanding of host-parasite interaction and evolution. His prediction has only recently come to fruition, especially with the advent of modern systematics and phylogenetics (Hugot et al., 2014), and in context with the maturation of molecular biology (Leles et al., 2012). In this article we have given information about 15 paleontological and archaeological sites in Russia where the parasites were found (Fig. 1; Table 1). 


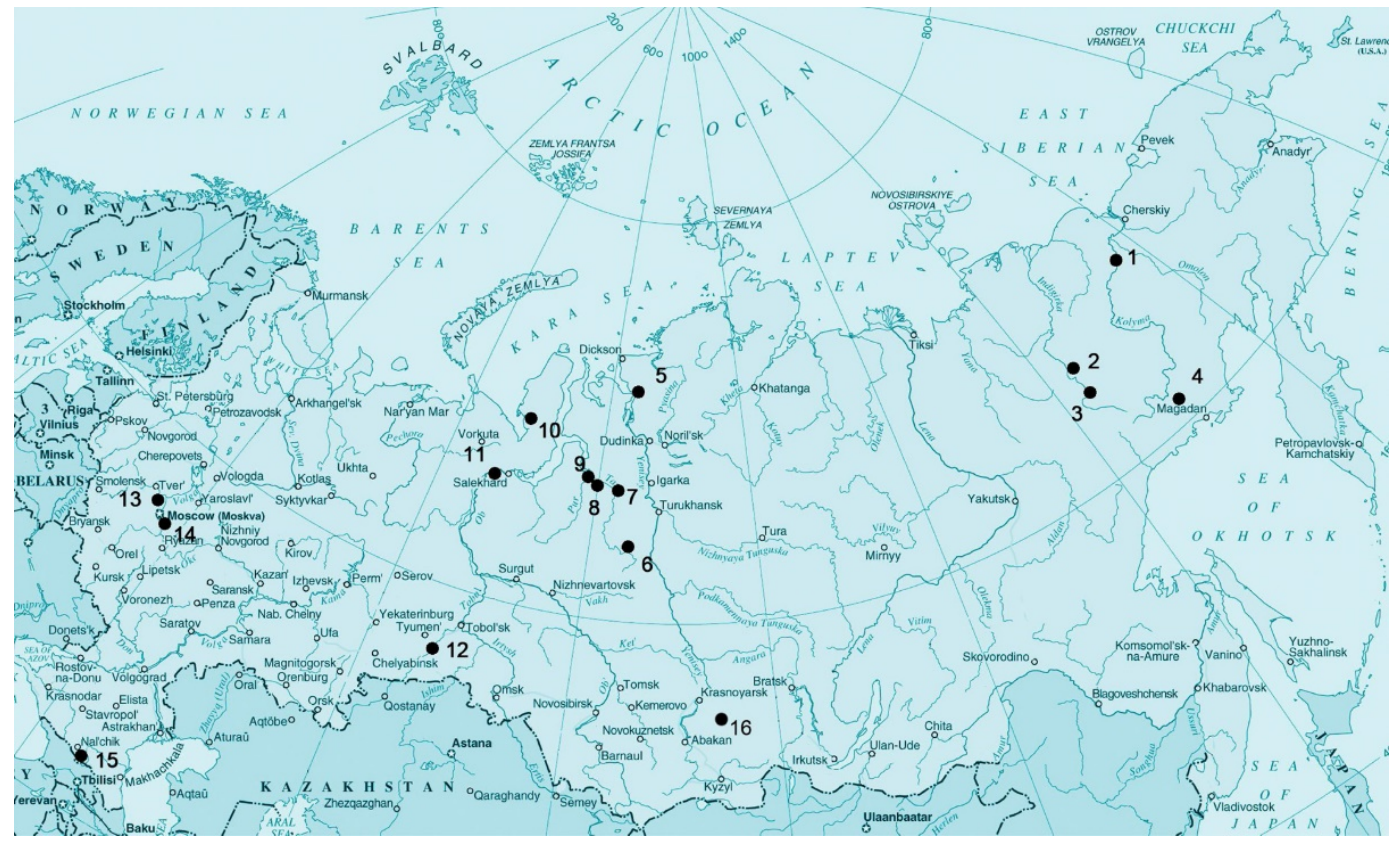

Figure 1. Paeontological and archaeological sites in Russia, where the parasites were found. 1. Berezovka River (right tributary of Kolyma River); 2. Balkhan Brook (the upper reaches of the Indigirka River) and Indigirka River; 3. Indigirka River; 4. Kirgilyah Creek (tributary of Bereleh River); 5. Sopochnaya Karga station (Taimyr peninsula); 6. KikkiAkki burial ground (Western Siberia); 7. Mangazeya (first Russian city in the Siberian Arctic); 8. Nyamboyto I burial grounds (Western Siberia); 9. Vesakoyaha II and Vesakoyaha IV burial grounds (Western Siberia); 10. Yarte VI, archaeological site in Yamal peninsula (Western Siberia); 11. Zeleny Yar burial ground (Western Siberia); 12. Maray I archaeological site Tuymen region (Western Siberia); 13. Zamostye 1 archaeological site; 14. Zamostye 2 archaeological site; 15. Kessarsky and Tseysky Gorges in North Ossetia; 16. Nefteprovod II burial ground (East Siberia).

Table 1. Published records of paleontological and archaeological sites in Russia classified by genus/ species, chronology, and origin structure

\begin{tabular}{|c|c|c|c|c|}
\hline Site names & Datations/periods & Origin structure & Data origin & Genus/species \\
\hline $\begin{array}{l}\text { Berezovka River } \\
\text { (right tributary } \\
\text { of Kolyma River) }\end{array}$ & $\begin{array}{l}44,000 \text { years } \\
\text { before present }\end{array}$ & $\begin{array}{l}\text { Mammoth } \\
\text { mummies }\end{array}$ & $\begin{array}{l}\text { Balyanitskiy- } \\
\text { Birulya (1909), } \\
\text { Zalenskiy (1909) }\end{array}$ & Cestoda? \\
\hline $\begin{array}{c}\text { Kirgilyah Creek } \\
\text { (tributary of } \\
\text { Bereleh River) }\end{array}$ & $\begin{array}{c}13,000-40,000 \text { years } \\
\text { before present }\end{array}$ & $\begin{array}{l}\text { Mammoth } \\
\text { mummies }\end{array}$ & Ivanova (1981) & Cestoda? \\
\hline $\begin{array}{l}\text { Sopochnaya Karga } \\
\text { station (Taimyr } \\
\text { peninsula) }\end{array}$ & $\begin{array}{l}45,000 \text { years } \\
\text { before present }\end{array}$ & $\begin{array}{l}\text { Mammoth } \\
\text { mummies }\end{array}$ & $\begin{array}{l}\text { Glamazdin et al. } \\
\text { (2014) }\end{array}$ & $\begin{array}{l}\text { Plathelminthes } \\
\text { types (Cestoda } \\
\text { classes), Nema- } \\
\text { thelminthes types } \\
\text { (Nematoda classes) }\end{array}$ \\
\hline Indigirka River & $\begin{array}{c}10,000-12,000 \text { years } \\
\text { before present }\end{array}$ & $\begin{array}{l}\text { Mummified } \\
\text { gophers }\end{array}$ & Dubinin (1948) & $\begin{array}{l}\text { Syphacia sp. } \\
\text { (Oxyuroidea) }\end{array}$ \\
\hline
\end{tabular}




\begin{tabular}{|c|c|c|c|c|}
\hline Site names & Datations/periods & Origin structure & Data origin & Genus/species \\
\hline $\begin{array}{l}\text { Balkhan Brook } \\
\text { (upper reaches of } \\
\text { the Indigirka } \\
\text { River) }\end{array}$ & $\begin{array}{l}37,000 \text { years } \\
\text { before present }\end{array}$ & $\begin{array}{l}\text { Mummified } \\
\text { remains of an } \\
\text { ancient horse }\end{array}$ & Dubinina (1972) & $\begin{array}{l}\text { Nematodes of the } \\
\text { suborder Stron- } \\
\text { gylata; shell of a } \\
\text { mite of the sub- } \\
\text { order Oribatea; } \\
\text { nematodes } \\
\text { (Alfortia edentates) }\end{array}$ \\
\hline Indigirka River & $\begin{array}{l}37,000 \text { years } \\
\text { before present }\end{array}$ & $\begin{array}{l}\text { Remains of a } \\
\text { mummified } \\
\text { bison }\end{array}$ & $\begin{array}{l}\text { Shakhmatova } \\
\text { (1988) }\end{array}$ & $\begin{array}{l}\text { Skrjabinagia } \\
\text { Kassimov, } 1942 \\
\text { genus Nematoda, } \\
\text { Trichostrongylidae }\end{array}$ \\
\hline $\begin{array}{l}\text { Kessarsky and } \\
\text { Tseysky Gorges } \\
\text { in North Ossetia }\end{array}$ & $\begin{array}{l}339 \pm 53 \text { to } 122 \pm 56 \\
\text { years ago }\end{array}$ & Domestic sheep & $\begin{array}{l}\text { Khrustalev and } \\
\text { Savinetsky (1992) }\end{array}$ & $\begin{array}{l}\text { Fasciola sp.; } \\
\text { Dicrocoelium sp.; } \\
\text { Trichuris sp.; } \\
\text { Trematoda gen. sp. }\end{array}$ \\
\hline $\begin{array}{l}\text { Archaeological sites } \\
\text { Zamostye } 1,2 \\
\text { Moscow region }\end{array}$ & $\begin{array}{l}\text { 7th to 5th } \\
\text { millennium BC }\end{array}$ & Dog coprolites & $\begin{array}{l}\text { Engovatova and } \\
\text { Khrustalev } \\
(1996)\end{array}$ & $\begin{array}{l}\text { Diphyllobothrium } \\
\text { sp., Spirometra } \\
\text { sp., Dioctophyme } \\
\text { renale, Alaria } \\
\text { alata, Capillariidae } \\
\text { gen. sp., } \\
\text { Opisthorchis felineus }\end{array}$ \\
\hline $\begin{array}{l}\text { Yarte VI } \\
\text { (archaeological } \\
\text { site on Yamal } \\
\text { peninsula) }\end{array}$ & 13th century & Dog coprolites & $\begin{array}{l}\text { Vizgalov et al. } \\
\text { (2013) }\end{array}$ & $\begin{array}{l}\text { Opisthorchis } \\
\text { felineus }\end{array}$ \\
\hline $\begin{array}{l}\text { Mangazeya } \\
\text { (first Russian city } \\
\text { in the Siberian } \\
\text { Arctic) }\end{array}$ & 17th century & Dog coprolites & $\begin{array}{l}\text { Vizgalov et al. } \\
\text { (2013) }\end{array}$ & $\begin{array}{l}\text { Opisthorchis } \\
\text { felineus, Diphyllo- } \\
\text { bothrium latum, } \\
\text { Trichuris (Tricho- } \\
\text { cephalus) sp., } \\
\text { Toxocara canis, } \\
\text { and Fasciola } \\
\text { hepatica }\end{array}$ \\
\hline $\begin{array}{l}\text { Zeleny Yar burial } \\
\text { ground (Western } \\
\text { Siberia) }\end{array}$ & 12th-13th centuries & $\begin{array}{l}\text { Human pelvic } \\
\text { soil }\end{array}$ & $\begin{array}{l}\text { Slepchenko et al. } \\
\text { (2015) }\end{array}$ & $\begin{array}{l}\text { Opisthorchis fe- } \\
\text { lineus }\end{array}$ \\
\hline $\begin{array}{l}\text { Kikki-Akki burial } \\
\text { ground (Western } \\
\text { Siberia) }\end{array}$ & 17th-19th centuries & $\begin{array}{l}\text { Human pelvic } \\
\text { soil }\end{array}$ & $\begin{array}{l}\text { Slepchenko and } \\
\text { Ivanov (2015) }\end{array}$ & $\begin{array}{l}\text { Diphyllobothrium } \\
\text { latum }\end{array}$ \\
\hline $\begin{array}{l}\text { Vesakoyaha II and } \\
\text { Vesakoyaha IV } \\
\text { burial grounds } \\
\text { (Western Siberia) }\end{array}$ & 19th century & $\begin{array}{l}\text { Human pelvic } \\
\text { soil }\end{array}$ & $\begin{array}{l}\text { Slepchenko et al. } \\
\text { (2016) }\end{array}$ & $\begin{array}{l}\text { Diphyllobothrium } \\
\text { latum; Taenia sagi- } \\
\text { nata }\end{array}$ \\
\hline $\begin{array}{l}\text { Nyamboyto I } \\
\text { burial grounds } \\
\text { (Western Siberia) }\end{array}$ & 19th century & $\begin{array}{l}\text { Human pelvic } \\
\text { soil }\end{array}$ & $\begin{array}{l}\text { Slepchenko et al. } \\
\text { (2016) }\end{array}$ & $\begin{array}{l}\text { Diphyllobothrium } \\
\text { latum }\end{array}$ \\
\hline
\end{tabular}




\subsection{Paleoparasitological discoveries}

First, in 1909, Vladimir Zalevskiy and Fadey Byalynitskiy-Biruley published detailed results of their study of the Berezovsky mammoth remains. The Berezovsky mammoth was an almost perfectly preserved mammoth found in 1901 on the Berezovka River (right tributary of Kolyma River). The published study included a description of mammoth anatomy as well as histology of its bones and soft tissues (Balyanitskiy-Birulya, 1909; Zalenskiy, 1909). Both authors reported pathological changes in the mammoth's stomach, including multiple hemorrhages (hematomas?) in submucosa and muscle layers. They describe: "accumulations of problematic entities in submucosa (muscularis serosae) of mammoth' stomach" [«скопления проблематических тел в подслизистой ткани (muscularis serosae) желудка мамонта».] The authors did not provide any explanation for the observed abnormalities. However, research on the Magadan mammoth, carried out by E. Ivanova 70 years later, inferred that the Berezovsky mammoth had a parasitic infection of some sort.

The Magadan baby mammoth was discovered in the Magadan region in 1977, near the town of Susuman. E. Ivanova studied a range of tissues from that mammoth. Her histological analysis of blood vessels and blood from the vena cava caudalis discovered round plaques ranging in size from 0.01 to $0.06 \mathrm{~mm}$, which E. Ivanova interpreted as helminth eggs. Furthermore, she discovered fragments of parasitic worms that measured $0.1 \times 0.05 \mathrm{~mm}$ as well as multiple cavities surrounding blood vessels where parasites matured during the initial phases of infection. Walls of vessels and surrounding tissues that were infected with parasites contained multiple hemorrhages (hematomas) and islands of necrotic tissue. In addition, E. Ivanova reported that the lobes of the thyroid gland were filled up with helminth eggs (Ivanova, 1981).

Comparing the "problematic entities" that were described and sketched by V. Zalevskiy and F. Byalynitskiy-Biruley in the stomach area of Berezovsky mammoth with the eggs and cysts found during the study of Magadan mammoth, E. Ivanova observed that these are identical. She also proposed that observed pathologies are consistent with chronic or acute cysticercosis of herbivorous and omnivorous mammals. For instance, similar histological changes are typical for acute cysticercosis in reindeer (Mitskevich, 1962; Ivanova, 1981).

A body of young male mammoth of species Mammuthus primigenius (Blumenbach, 1799) was discovered in 2012, not far from Sopochnaya Karga station, hence dubbed Sopochnaya Karga mammoth. Soft tissues on the right side of the body were partially preserved. The mammoth body also retained fragments of heart, liver, and the contents of large intestine. Fragments of muscle, liver, and contents of rectum were examined for parasitic infection. Eggs of multiple helminths, including those of Plathelminthes and Nemathelminthes, types of Cestoda and Nematoda classes, respectively, were found (Glamazdin et al., 2014).

In January 1968, mummified remains of an ancient horse were found at a gold mine in Selerikan in the Balkhan brook valley (the upper reaches of the Indigirka River), at a depth of 8-9 $\mathrm{m}$ in the permafrost. The remains have an absolute dating of 37,000 years (radiocarbon dating of the plant remains from the stomach) (Arslanov and Chernov, 1977). During analysis of the intestinal contents the researchers found in the colon a few nematodes of the suborder Strongylata and a shell of a mite of the suborder Oribatea. Analysis revealed 4 
entire males, 2 males without anterior sections, 6 separated anterior sections, and 2 fragments of midsection. Entire females were not present. The analysis of the material showed nematodes belong to Alfortia edentatus (Dubinina, 1972).

The next paleoparasitological works were published after World War II in the USSR and all of them have been carried out on the material of Pleistocene animals. V. Dubinin studied mummified gophers from the Indigirka River, of absolute dating of 10,000 to 12,000 years. The guts of mummified rodents contained the nematode Syphacia sp. (Oxyuroidea) (Dubinin, 1948).

While analyzing mummified bison, dated about 37,000 years before present, Shakhmatova found nematode genus Skrjabinagia Kassimov, 1942 (Nematoda, Trichostrongylidae) (Shakhmatova, 1988).

Savinetsky and Khrustalev also performed helminthological analysis of excrement samples collected from Pleistocene deposits of Siberian goat droppings. They were found in a Yaroldzyhtynsky cave in southern Mongolia dating 33,653 $\pm 1,638$ years ago. The samples revealed eggs of the helminth genus Nematodirus. The researchers continued their investigations of ancient parasites in 1992 and published another article revealing the results of the analyses of dung deposits from the caves and places of animals breeding. They analyzed 77 samples from five locations in North Ossetia, Turkmenistan, and Mongolia. However, the authors simply listed the presence of the helminth genera Fasciola sp., Dicrocoelium sp., Trichuris sp., Capillaria sp., Dicrocoelium sp., Nematodirus sp., and Oxyurida without discussion or interpretation of the results. In conclusion the authors wrote how advanced a paleoparasitological analysis is for studying the history of the worm prevalence, speciation, the formation of helminth infections, migration routes and identification of domesticated animals, and for paleoecological studies (Knyazev and Savinetsky, 1992).

\subsection{Establishment of archaeological parasitology in Russia}

Archaeological parasitology incorporates knowledge of past human behavior in reconstruction infection patterns. This includes human companion and food animals. The aforementioned articles just stated the presence of intestinal parasites in the fossils. However, in 1991 an article was published in the USSR that described some interesting results from archaeological contexts. Khrustalev and Savinetsky applied a helminthological method to reconstruct the history of sheep grazing in their study area. The authors analyzed sediments of sheep excrement of $42 \mathrm{~cm}$ in depth, which were located at an altitude of 1,800 m above the sea level in a rock shelter in Kessarskoe and Tseyskoe Gorges in North Ossetia and dated from $339 \pm 53$ to $122 \pm 56$ years ago. Helminthological results showed that helminth eggs of Fasciola sp., Dicrocoelium sp., Trichocephalus sp. were present. Moreover, the latter two parasites were distributed along the deposition profile quite evenly. Pathoecologically, the presence of Fasciola sp. in the layers allowed authors to split the sediments into two parts. The upper part lacked the eggs of Fasciola sp. The authors suggested that the eggs belonged to Fasciola hepatica due to the fact that they are often present among sheep. An obligate intermediate host of Fasciola hepatica is a small pond snail (Galba truncatula) whose biology covers water-meadows and small well-warmed ponds that are missing in the nearby area. Therefore, the authors inferred that the sheep were infected with F. hepatica due to an old practice in these areas of agisted (boarded) ranching. This type of 
ranching involved moving the sheep from the local area to plains with ponds. The ponds are the nidi of infection. The ponds with the intermediate snail host were present and maintained the cycle of fluke infection. After World War II, pasturing in the plains was stopped, thus eliminating any connection between the sheep and its intermediate host, a small pond snail, which resulted in the termination of the fascioliasis among sheep (Khrustalev and Savinetsky, 1990). Pathoecologically, this shows that isolating the sheep flocks from the nidus of transmission reduced infection.

In 2013 Savinetsky and Khrustalev issued an article in the International Journal of Paleopathology. The authors summarized all their own findings in parasitology in Central Asia, the North Caucasus, and Central European part of Russia in the range of 38,000 years BC to the present time. The authors stated that the results of parasitological analysis of coprolites and feces of animals (including dogs) provide important data for reconstruction of health, food, and the environment of humans. The distribution of eggs of parasites can give important information about pasturing of livestock, their migration routes, breeding features, the formation of zoonotic diseases, etc. (Savinetsky and Khrustalev, 2013).

After a hiatus for more than 10 years, one of the authors (Khrustalev) analyzed helminth eggs from Russian archaeological material for the first time (Engovatova and Khrustalev, 1996). Analysis of two dog coprolites from Zamostye 1, a Neolithic archaeological site, and of 34 dog coprolites from Zamostye 2, a Mesolithic archaeological site, provided interesting data relevant to both human and dog infection. The sites belong to Lyalovskaya and Verkhnevolzhskaya archaeological cultures, respectively, and are dated from the beginning of the 7th to the middle of 5th millennium BC. The samples revealed eggs of Diphyllobothrium sp., Spirometra sp., Dioctophyme renale, Alaria alata, Capillariidae sp., and Opisthorchis felineus (Engovatova and Khrustalev, 1996). From the pathoecological perspective, a high rate of helminth infection among the dogs, in particular Diphyllobothrium sp. and $O$. felineus, suggests that people and animals largely consumed fish during the Mesolithic and Neolithic periods in Moscow suburbs. The other species are more rarely found infecting humans.

In 2011, an article was published about the analysis of dog coprolites from the Maray I settlement, the transition from the Bronze to the Iron Age in the forest-steppe zone of Western Siberia. The study of coprolites revealed larvae of Strongyloides papillosus and O. felineus. According to the authors, the dogs were infected by these worms while consuming culled hides and guts of the slaughtered cattle and raw fish of carp family (Zach et al., 2011).

The analysis of dog coprolites from Yarte VI settlement, located in the lower reaches of the Yuribey River, on the Yamal Peninsula, revealed eggs of $O$. felineus in one of the dog coprolites. According to the authors, contamination with the helminth eggs could have occurred only in the Ob-Irtysh basin, as there are no conditions for the parasitic existence in Yamal (Vizgalov et al., 2013). These data are confirmed by ethnographic observations. For example, among the Nenets, seasonal migrations Yamal Nenets characterized by a north-south direction, and are made twice a year, in spring and autumn: from north to south and back again. Nenets reindeer graze in the north of the Yamal Peninsula in the summer; they graze their herds in the lower reaches of the Ob River in the winter (Krupnik, 1989; Dunin-Gorkavich, 1904). Therefore, pathoecologically, transhumance is key to 
exposing dogs and humans to infection. As noted lower for the First Russian Siberian City, $O$. felineus can infect humans and cause serious liver disease.

In 2014 during excavations of the Nefteprovod II burial ground in East Siberia dated from the early/middle Bronze Age. Analysis of a sediment sample from the sacral region of the pelvis revealed the presence of Taenia sp. eggs. The authors have been shown, this individual was likely consuming raw or undercooked meat of roe deer, red deer, or elk infected with Taenia. The individual was most likely infected with the tapeworm through the consumption of raw brain tissue from a wild ungulate that was infected with Taenia sp. This ungulate was possibly roe deer, red deer, or elk. This finding represents the oldest case of a human infected with Taenia sp. from Eastern Siberia and Russia (Slepchenko et al., 2017).

Another study was carried out in the first Russian city of the 17th century in the Siberian Arctic-Mangazeya. Thirty-one samples from the organic soil and dog coprolites underwent a paleoparasitological analysis. The analysis revealed a high rate of parasitic worms. Eggs of helminth genera O. felineus, Diphyllobothrium latum, Trichuris (Trichocephalus) sp., Toxocara canis, and Fasciola hepatica were found in the samples. However, the authors just stated the presence of the helminth eggs without giving any further pathological interpretation that is very important for archaeologists (Vizgalov et al., 2013). From our perspective, the parasite pathoecology was defined by fish dependence, fecal contamination, and human-dog interaction. The parasites derived from fish infect humans and dogs. Therefore, it is possible that humans were infected. T. canis is a zoonotic parasite. Normally, the worms infect dog intestinal tracts where eggs are laid. When humans ingest the eggs, the nematode juveniles migrate through the tissues and can migrate to the central nervous system or eyes. This phenomenon is called visceral larva migrans. A thorough archaeological study might reveal the specific features that were the nidi of infection.

In 2014 during excavations of a medieval Zeleny Yar burial ground, we selected soil samples from the pelvic region of an infant under the age of 1 year old. Paleoparasitological analysis revealed eggs of $O$. felineus in the sample, which suggests that the medieval population consumed raw or undercooked fish from a very young age (Slepchenko et al., 2015). This analysis confirms that humans were infected. This possibility was inferred by the analysis of dog companion animals in studies summarized about. However, absolute evidence of infection was confirmed by this study.

Since the field season of 2013, researchers from the Institute of Northern Development (Tyumen) have began to collect soil samples from the pelvic region and coprolites from burial grounds located in Western Siberia. It was the first time when parasitological investigations were carried out from human burials. They analyzed soil samples collected during excavations of Selkup Kikki-Akki burial ground, dated from the 17th to the first half of 19th centuries. Pathoecologically, the presence of the broad tapeworm eggs (Diphyllobothrium $\mathrm{sp}$.) allowed the researchers to determine transmission pathways of helminthiasis infection and infer that the Selkups consumed raw or undercooked fish. The absence of $O$. felineus eggs and cases of opisthorchiasis led the authors to infer that the population made few or no seasonal migrations to the Ob-Irtysh basin for fishing where the rate of contaminated fish is very high. Therefore, the Selkups migration paths from the burial ground Kikki-Akki were limited within the Taz River, or tended toward the Yenisei and Pur river 
basins where opisthorchiasis is not present (Slepchenko and Ivanov, 2015). Pathoecologically, limited population movement prevented this group of people from moving into the edemic area for O. felineus and the nidi of infection for this species. However, the Selkups became infected from their reliance on uncooked fish.

In 2014 soil samples were collected from the pelvic region from Vesakoyaha II-IV and Nyamboyto I burial grounds which belonged to the Taz Nenets (Slepchenko et al., 2016). It was inferred by the funeral features and the specific tools that the burial grounds date back to the 19th to the early 20th centuries, respectively. An interest in these burial grounds arose over the diversity of their subsistence activities. According to ethnographic data, the first two burial grounds were left by the Nenets who were reindeer breeders, while the latter one was based solely on fishing. The soil samples from the burial grounds revealed the eggs of Diphyllobothrium sp. and Taenia sp. The study showed that diphyllobothriasis prevailed in all the groups of the Taz Nenets. At the same time the Nyamboyto Nenets largely consumed almost raw fish from the Nyamboyto lake. The Nenets who had left the burial ground at the Vesakoyaha River had a more diverse diet which also included reindeer meat. The investigation revealed that all the groups of the Taz Nenets began to give raw fish to their children from the age of about 3 years old.

Eggs consistent with the beef tapeworm, Taenia saginata, were found in the Vesakoyaha III burial grounds. This is a surprising find since cattle were not known to the population. The analysis does makes sense in context of Russian ethnographic observations of raw reindeer cerebrum being eaten by the indigenous population and laboratory experiments of beef tapeworm infections in reindeer. Ethnographers connected reindeer brain consumption with beef tapeworm infection. Experiments showed that beef tapeworm larvae survive only in the brain tissue of reindeer, not in muscle or other organs (Blazek et al., 1986a; Kirichek et al., 1984). The experiments corroborated to the ethnographic observations connections between diet and infection (Blazek et al., 1986a; Kirichek et al., 1984). This unique variant of the beef tapeworm life cycle defined experimentally and ethnographically has a time depth demonstrated by archaeology.

This demonstrates that archaeology, along with epidemiological observation and laboratory experimentation, can define the origin of a little known and surprising life cycle variant of a common species of tapeworm. The direct evidence of parasitic diseases in the Taz Nenets group allows us to better understand the subsistence activities and food patterns of the Nenets from the Taz lower reaches and broadens our knowledge about their health status (Slepchenko et al., 2016).

Thus, the history of pathoecology shows us that it is a universal study which provides answers to numerous questions. Besides, the obtaining information that can be used in biology, medicine, and the humanities, parasitological results are an important contribution to archaeology, and help to obtain new independent information about paleodiet, food patterns, and cooking methods. They also help to determine a social status of the buried humans, lifestyle, contacts, and migrations of ancient populations. The study of crossinfection between humans and animals is a good source of information about cattle breeding, its distribution, quantitative changes in livestock, and migration paths of pastoralists. Paleopathology is interested in health conditions and the sanitary status of groups of 
ancient populations as well as in the connection of various parasitic diseases with paleopathological changes in human skeletons (cribra orbitalia, porotic hyperostosis, etc.).

\subsection{Beyond the past: archaeological parasitology and the future}

The perspectives applied in archaeological parasitology have relevance to developments in parasitology that address human-parasite interactions in a rapidly change global environment. One of these is the Stockholm Paradigm (Araújo et al., 2015; Hoberg and Brooks, 2015). Although the paradigm has a distinct focus on the future of emerging diseases in a warming world, its principles can be applied to the past. The paradigm developed in response to a paradox: parasite evolution does not follow the paths predicted by standard theory. The traditional theory was that host-parasite relationships are tightly coevolved and that parasites tend to specialize on a restricted group of hosts. This would predict that host switching and emergent parasite infections would be rare. However, data from the modern world, and from archaeology, show that emergent and reemergent infections are the norm. This is clear from the Russian data reviewed here. Most of the parasites found are generalists that show limited coevolutionary specialization. The Stockholm Paradigm has several components. One of these, ecological fitting, is relevant to the data from Russia (Araújo et al., 2015). The major features of successful host switching are compatibility and opportunity. Compatibility is the relative fit of the parasite to a new host. Importantly, the selective pressure cannot be strong enough to block a colonizing parasite population. The case of the beef tapeworm in the reindeer brain represents partial compatibility. Although emergent larvae die in most body tissues, they survive and encyst in the brain. The second aspect of ecological fitting, opportunity is also represented in the beef tapeworm-reindeer brain example. Opportunity occurs when the established host, potential host, and parasites come into contact. For the Vesakoyaha population, once infective eggs were dispersed by humans in the geography shared by humans and reindeer, the infection cycle was established. In this case, this was a partial host switch facilitated by an incomplete physiological blockage of infection within the reindeer.

Another new perspective looks at parasitism across time to predict where infections with specific parasites will occur in the future. This is the DAMA protocol (Brooks et al., 2014). DAMA stands for Documentation-Assessment-Monitoring-Action. The protocol is designed to develop a preemptive capability to comprehend, anticipate, and respond to the parasitological outcomes of accelerating environmental change. It is designed to provide crucial data regarding parasite evolution, ecology, and epidemiology across host taxa, parasite taxa, geographical area, and ecosystem classes. For DAMA, archaeoparasitology could be a foundation for documenting human-host parasite interactions relating to assessment of the emergence potential of parasites in humans in changing climates. Therefore, past information can become a predictive tool to anticipate where parasite expansion and/or reemergence might occur as climate changes.

\section{Conclusion}

Russian parasitology includes ethnographic and experimental research bases that developed in tandem with a strong theoretical perspective established by Y. Pavlovsky. The fact 
that Y. Pavlovsky invented the term paleoparasitology is significant. Although Ferreira is more widely credited with introducing the term in 1978 (Novo and Ferreira, 2016), clearly Pavlovksy predated that work. Importantly, Pavlovsky's theoretical perspective for the field was the broad understanding of host-parasite evolution, which has grown to be a central issue in emerging parasitological theories such as the Stockholm Paradigm and DAMA.

Archaeological parasitology is a rapidly growing field that is expanding in different countries. The territory of the Russian Federation has been a huge blank spot regarding our knowledge of parasite transmission in ancient times. Now with new archaeological parasitology analyses, that gap is being filled. The theoretical construct provided by Y. Pavlovsky is an important addition and should be incorporated in the archaeological reconstruction of parasite transmission.

Russian archaeologists have a growing idea of this method of research and of the valuable information it can provide. Unless soil samples from burial grounds are recovered for parasitological and pathoecological analysis, we irretrievably lose a huge source of information that could be obtained. Therefore, an energetic education campaign must be done to familiarize archaeologists with this information potential and the methods for recovery.

Since the beginning of systematic collecting of soil samples, coprolites, etc., the researchers of the Institute of the Problems of Northern Development, a subdivision of Federal Tyumen Scientific Centre of Siberian Branch of the Russian Academy of Sciences, have made a significant contribution to the development of the knowledge about various aspects of the ancient population that lived in the territory of Russia. Importantly we have shown for the first time that archaeology contributes to the current evolutionary theory of host switching, proposed as a component of the new Stockholm Paradigm of parasite evolution (Araújo et al., 2015; Hoberg and Brooks, 2015).

Acknowledgments - The authors would like to thank Dr. Johnica Morrow, University of Nebraska, for editing the final manuscript.

\section{References}

Araújo, S.B.L., Braga, M.P., Brooks, D.R., Agosta, S.J., Hoberg, E.P., von Hartenthal, F.W., Boeger, W.A., 2015. Understanding host-switching by ecological fitting. PLoS One 10 (10), e0139225.

Arslanov, H.A., Chernov, S.B., 1977. On the absolute age selerikansky fossil horse. The fauna and flora Quaternary northeast Siberia. Nauka Leningrad (in Russian).

Balyanitskiy-Birulya, F.A., (1909). Histological and chemical examination of tissues Berezovsky Mammoth. In: The scientific results of the expedition of the Imperial Academy of Sciences for the mammoth excavation have found on the Berezovka River in 1901. 2. Sankt-Peterburg.

Blazek, K., Kirichek, V.S., Schramlova, J., 1986a. Pathology of experimental Cysticercus bovis infection in the reindeer (Rangifer tarandus Linne, 1758). Folia Parasitol. (Praha) 33, 39-44.

Brooks, D., Hoberg, E.P., Boeger, W., Gardner, S., Galbreath, K., Herczeg, D., Mejia-Madrid, H., Racz, G., Tsogtsaikhan, A., 2014. Finding them before they find us: informatics, parasites and environments in accelerating climate change. Comparat. Parasitol. 81, 155-164. 
Bryant, V.M., Reinhard, K.J., 2012. Coprolites and archaeology: the missing links in understanding human health. In: Hunt, A. (Ed.), Vertebrate Coprolites 51. New Mexico Museum of Natural History and Science Bulletin, pp. 379-387.

Dittmar, K., Reinhard, K.J., Araújo, A., 2012. The study of parasites through time: archaeoparasitology and paleoparasitology. In: Grauer, A. (Ed.), Paleopathology: A Companion Volume. Wiley/Blackwell Press, Hoboken, pp. 170-190.

Dubinin, V.B., 1948. Find of pleistocene louse and nematode in corpses of fossil gophers. Doklady AN SSSR 62, 417-420 (in Russian).

Dubinina, M.V., 1972. Nematode Alfortia edentata (Looss, 1900) from intestines of late pleistocene horse. Parasitology 6, 443-444 (in Russian).

Dunin-Gorkavich, A.A., 1904. Geographic sketch tobolsk north. Izvestia the Russian Geographical Society. SPb I-II (in Russian).

Engovatova, A.V., Khrustalev, A.V., 1996. Coprolites from stone age sites of Podmoskovye. Tverskoy sbornik 2, 148-154 (in Russian).

Glamazdin, I.G., Serdyuk, N.V., Panova, O., Tikhonov, A.N., Mashchenko, E.N., 2014. Parasitological studies of organs and tissues sopkarginsky mammoth (M Primigenius) (Taimyr, Russia). Theory Pract. Parasit. Anim. Dis. 15, 73-76 (in Russian).

Hoberg, E.P., Brooks, D.R., 2015. Evolution in action: climate change, biodiversity dynamics and emerging infectious disease. Home I Philos. Trans. R. Soc. London Series B. http://dx.doi.org/10.1098/ rstb.2013.0553

Hugot, J.P., Gardner, S.L., Borba, V., Araújo, P., Leles, D., Stock Da-Rosa, A.A., Dutra, J., Ferreira, L.F., Araújo, A., 2014. Discovery of a 240 million year old nematode parasite egg in a cynodont coprolite sheds light on the early origin of pinworms in vertebrates. Parasites Vectors 7, 486.

Ivanova, E.I., 1981. The morphology of fragments of blood vessels and some organs mammoth neck. In: Vereshagin, N.K. (Ed.), Magadansky Mammoth (Mammuthus Primibenius (Blumenbash). Nauka Press, Moscow, pp. 128-154 (in Russian).

Khrustalev, A.V., Savinetsky, A.B., 1990. Using helminthological analysis of fossil animals for paleoecological studies. Ecology 4, 83-85 (in Russian).

Khrustalev, A.V., Savinetsky, A.B., 1992. Occurrence of helminths' eggs in quaternarydeposits of animals' feces. Parasitology 26, 122-129 (in Russian).

Kirichek, V.S., Belousov, M.N., Nikitin, A.S., 1984. New data on the epidemiology of taeniarhynchiasis in regions of the Far North in the USSR (based on observational data in the Yamal-Nenets Autonomous Okrug). Meditsinskaia Parazitologiia (Mosk) 6, 27-33.

Knyazev, A.V., Savinetsky, A.B., 1992. Deposits of subfossil faeces of ungulates in North Osetia. In: Dinesman, L.G. (Ed.), Historical Ecology of Wild and Domestic Ungulates. Nauka Press, Moscow, pp. 147-164 (in Russian).

Krupnik, I.I., 1989. Arctic Encyclopedia. Nauka Press, Moscow, pp. 272 (in Russian).

Leles, D., Gardner, S.L., Reinhard, K., Iñiguez, A., Araújo, A., 2012. Are Ascaris lumbricoides and Ascaris suum a single species? Parasites Vectors 5, 42.

Martinson, E., Reinhard, K.J., Buikstra, J.E., Dittmar, K., 2003. Pathoecology of chiribaya parasitism. Memorias do Instituto do Oswaldo Cruz 98, 195-205.

Mitskevich, V. Yu, 1962. Pathogens cestodosis reindeer. Abstracts of Scientific. Conf. Union Society Helminthologists USSR Academy of Sciences. Nauka Press, Moscow, pp. 10-14 (in Russian).

Novo, S.P., Ferreira, L.F., 2016. The paleoparasitology in Brazil and findings in human remains from South America: a review. Korean J. Parasitol. 54, 573-583. 
Pavlovsky, E.N., 1946. Handbook on Parasitology of Man and Theory on Vectors of Transmissive Diseases. Leningrad, Moscow.

Pavlovsky, E.N., 1966. Natural Nidality of Transmissible Diseases, with Special Reference to the Landscape Epidemiology of Zooanthroponoses. University of Illinois Press, Urbana.

Reinhard, K.J., Araújo, A., 2012. Synthesizing archaeology with parasitology in paleopathology. In: Buikstra, J., Roberts, C. (Eds.), A Global History of Paleopathology. Oxford University Press, Oxford, pp. 751-764.

Reinhard, K.J., Araújo, A., 2014. Prehistoric earth oven facilities and the pathoecology of chagas disease in the lower pecos canyonlands. J. Archaeolog. Sci. 53, 227-234.

Reinhard, K.J., Araújo, A., 2016. Prehistoric pathoecology as represented by parasites of a mummy from the Peruaçu Valley, Brazil. Korean J. Parasitol. 54, 585-590.

Reinhard, K.J., Bryant, V.M., 2008. Pathoecology and the future of coprolite studies. In: Stodder, A.W.M. (Ed.), Reanalysis and Reinterpretation in Southwestern Bioarchaeology. Arizona State University Press, Tempe, pp. 199-216.

Reinhard, K.J., 2008a. Pathoecology of two ancestral pueblo villages. In: Reitz, E.J. (Ed.), Case Studies in Environmental Archaeology, 2nd edition. Plenum Press, New York, pp. 191-210.

Reinhard, K.J., 2008b. Parasite pathoecology of Chacoan Great Houses. In: Reed, P.F. (Ed.), Chaco's Northern Prodigies Salmon, Aztec, and the Ascendancy of the Middle San Juan Region After 1100 CE. University of Utah Press, Salt Lake City, pp. 86-95.

Savinetsky, A.B., Khrustalev, A.V., 2013. Paleoparasitological investigations in Mongolia, middle asia and Russia. Int. J. Paleopathol. 3, 176-181.

Shakhmatova, V.I., 1988. New species of genus Skrjabinagia Kassimov, 1947 (Nematoda, Trichostrongylidae) from Fossil Bison. Taxonomy of Siberian Animals. Novosibirsk, 14-19 (in Russian).

Slepchenko, S.M., Ivanov, S.N., 2015. Paleoparasitological analysis of soil samples from the KikkiAkki burial ground of the 17th-19th centuries in West Siberia, Russia. J. Archaeol. Sci.: Rep. 2, 467-472.

Slepchenko, S.M., Gusev, A.V., Ivanov, S.N., Svyatova, E.O., 2015. Opisthorchiasis in infant remains from the medieval Zeleny Yar burial ground of XII-XIII centuries AD. Memórias do Instituto Oswaldo Cruz 110 (8), 974-980.

Slepchenko, S.M., Ivanov, S.N., Bagashev, A.N., Tsybankov, A.A., Slavinsky, V.S., 2016. Traditional living habits of the Taz Tundra population: a paleoparasitological study. Korean J. Parasitol. 54 (5), 617-623.

Slepchenko, S.M., Ivanov, S.N., Vybornov, A.V., Tsybankov, A.A., Slavinsky, V.S., Lysenko, D.N., Matveev, V.E., 2017. Taenia sp. in human burial from Kan River: East Siberia. Memorias do Instituto do Oswaldo Cruz 112, 387-390.

Vizgalov, G.P., Kardash, A.V., Kosintsev, P.A., Lobanova, T.V., 2013. Historical ecology of the population of the north of Western Siberia, AMB Yekaterinburg. Nefteyugansk. 376 pp (in Russian).

Zach, V.A., Tsembalyuk, S.I., Siben, A.N., 2011. Parasites in human life: formulation of the problem. Proceedings of the Ecology of Ancient and Traditional Societies, Tyumen, 14-18 November 2011, IPDN SB RAS, Tyumen, p. 107-110.

Zalenskiy, V.V., 1909. Microscopic examination of certain organs of the mammoth found on the Berezovka River. In: The scientific results of the expedition of the Imperial Academy of Sciences for the mammoth excavation have found on the Berezovka River in 1901. 2. Sankt-Peterburg, pp. 21-35. 